are active, and it may be that the phosphorylated adenosines (and guanosines?) occupy a unique place in the control of growth, as suggested recently by Potter ${ }^{9}$.

Recently, Leonian and Lilly ${ }^{10}$ have sta'ed that the yeast growth activity commonly attributed to unknown factors in yeast and tissue extracts is nonexistent and may be duplicated by adding greatly increased quantities of certain members of the vitamin $B$ complex (notably inositol, biotin and pantothenic acid) to the medium. In partial confirmation of this we find that tripling the quantities of these vitamins in our medium (that is, using per $\mathrm{ml}$. inositol, $300 \mathrm{mgm}$; calcium pantothenate, $360 \gamma$; and biotin, $1 \cdot 2 \gamma$ ) raises our $24-\mathrm{hr}$. yeast crop from $1.05 \mathrm{mgm}$. to $1.6 \mathrm{mgm}$. in a typical experiment. However, further addition of the wound hormone preparation in quantities of $0.14 \mathrm{mgm}$. per $\mathrm{ml}$., $0.2 \mathrm{mgm}$. per $\mathrm{ml}$., and $0.56 \mathrm{mgm}$. per ml., gave respectively crops of $2 \cdot 04 \mathrm{mgm} ., 2 \cdot 28 \mathrm{mgm}$., and $2.46 \mathrm{mgm}$. Discussion with Dr. Lilly suggests that the difference between his finding and ours lies in the yeast growth period. In the $72-\mathrm{hr}$. period used by Leonian and Lilly the vitamins appear to obliterate the effect of other substances in the wound hormone and other extracts. This is not evident in the 24-hr. period used by Loofbourow and by us. It would thus appear that the additional proliferants (presumably nucleotides and nucleosides) in our preparations affect primarily the rate of yeast proliferation rather than the ultimate crop. This is also indicated by data of Loofbourow ${ }^{2}$. Experiments will be carried out to confirm this.

In summary, the nucleosides adenosine and guanosine, alone or combined with each other or with yeast adenylic acid, exert growth effects on yeast. Such substances, together with known growth factors, would seem to be present in wound hormone preparations from ultra-violet injured yeast cells. These substances exert a slight direct metabolic effect on yeast as observed manometrically. It is probable that these substances exert their effect on rate of yeast proliferation rather than on ultimate crop.

We wish to thank Sr. Mary of Lourdes McDevitt, I.H.M., for technical assistance, and Dr. C. N. Frey of the Fleischmann Laboratories for gifts of adenosine, guanosine and adenylic acid. The other sample of adenylic acid was purchased from Hofmann-La Roche as "adenosine phosphoric acid".

Elton S. Cook.

Sr. Ann Gertrude Cronin, S.C.

Cornelius W. Kreke.

Sr. Thomas Mary Walsh, O.P.

Institutum Divi Thomae, Cincinnati, Ohio.

Sept. 6. ${ }^{1}$ Loofbourow, J. R., NATURE, 150, 349 (1942); Biochem. J., 36,

${ }^{2}$ Cook, E. S., Loofbourow, J. R., and Stimson, M. M., Atti $X^{\circ}$ congr. intern. chim., 5, 26 (1939). Loof bourow, J. R., Cook, E. S., and intern. chim., 5, 26 (1939). Loof bourow,

3 Davidson, J. N., Biochem. J., 34, 1537 (1940).

- Cook, E. S, and Cronin, A. G., Studies Inst. Divi Thomae, 3, 205 (1941); NATURE, 150, 93 (1942).

${ }^{5}$ Williams, R. J., and Saunders, D. H., Biochem. J., 28, 1887 (1934).

${ }^{6}$ Englert, Sr. M. E. (personal communication).

7 Cook, E. S., Walter, E. M., and Eilert, M. R., Proc. Soc. Exp. Biol. Med., 44, 547 (1940).

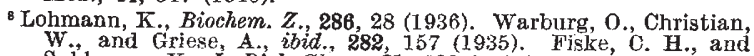
Subbarow, Y., J. Biol. Chem., 81, 629 (1929).

- Potter, V. R., A.A.A.S. - Gibson Isiand Conference on Chemical Growth Factors, August 2, 1943.

${ }^{10}$ Ieonian, L. H., and Lilly, V. G., J. Bact., 45, 191 (1943).

\section{Chemical Nature of Chromosomes}

THE staining properties of chromosomes have hitherto been regarded as due to their content of nucleic acid. Recently, however, Stedman and Stedman $^{x}$ have demonstrated the presence in animal chromosomes of a new protein, chromosomin, which they have shown not only to be the principal component of the chromosomes but also responsible for their staining properties. Part of their proof depended on the demonstration of the fact that when chromosomin, isolated from animal nuclei, is introduced into the dye solution formed by the interaction of hydrolysed deoxyribose nucleic acid and Feulgen's reagent (a solution which I propose to term 'developed nucleal stain'), it takes up the dye in exactly the same way as do the chromosomes. It is clear that if the Stedmans' interpretation of the mechanism of the normal Feulgen technique is correct, it should be possible to stain chromosomes directly with the developed nucleal stain. That this is the case is shown by the results, illustrated in the accompanying photomicrographs, which I have obtained with this stain on plant cells. This result provides confirmatory evidence of those of the Stedmans.

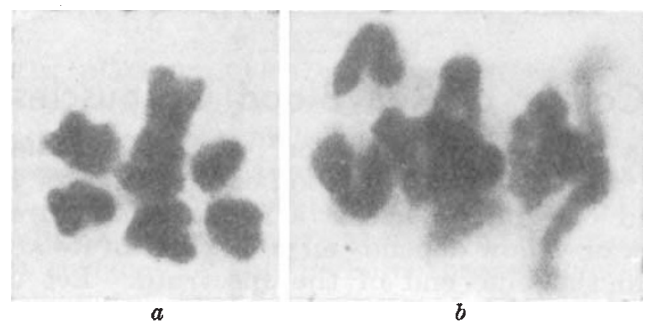

FIRST METAPHASE, (a) POLAR, (b) LATERAI VIEW, IN POLLEN MOTHER-OELLS OF CERTAIN SPECIES OF ALLIUM (FIXED IN AOETICALCOHOL) STAINED WITH DRVELOPED NUCLEAL STAIN. $\times$ c. 1800.

The new process has certain advantages over other nuclear stains. A simple technique has been developed for its use, the details of which will be published elsewhere.

My thanks are due to Dr. E. Stedman for placing at my disposal the new stain and for his friendly co-operation.

Department of Botany,

H. C. Choudhuri.

University,

Edinburgh.

Sept. 28.

${ }^{2}$ Stedman, E., and Stedman, E., NATURE, 152, 267 (1943).

\section{A New Rapid Method for Penicillin Assay}

VARIOUS methods of testing penicillin are in use in different laboratories, and while the accuracy of some of them is quite high, they all suffer from the disadvantage that some $12-18 \mathrm{hr}$. are required to obtain a result of any accuracy. Such a time-lag is a serious disadvantage in studying the production of penicillin--as the rapid change of $p \mathrm{H}$ which occurs under certain conditions makes it essential that harvesting should be carried out with the least delay if serious loss of activity is to be avoided.

The test outlined below, which has been in use for some time in these laboratories, has, in addition to its speed, other advantages. It is economical in space and materials, sterile technique is unnecessary 